\title{
CORRESPONDENCE
}

\section{ARCTIC INSTITUTE OF NORTH AMERICA: APPLICATIONS FOR RESEARCH SCHOLARSHIPS}

I am pleased to write that the Arctic Institute is inviting applications from research scientists interested in Arctic and sub-Arctic North America and in Antarctica. The aims of the institute's grant-in-aid programme, which last year numbered thirty-five awards ranging in value from $\$ 400$ to $\$ 10,000$, are to support the work of experienced field scientists, and to introduce other competent researchers to polar science. The institute favours no particular scientific disciplines, but appraises proposals on the basis of their individual excellence. Grants are usually made for a one-year period.

Opportunities for field research in Arctic Alaska and Canada have burgeoned since the IGY. Today the Institute can assist researchers in getting the use of laboratory facilities and field stations for many kinds of work. For example, the Office of Naval Research's Arctic Research Laboratory at Point Barrow, Alaska, offers excellent laboratory and logistical facilities for work in oceanography, sea ice, ecology, geology and soil science, and Arctic climatology. The Institute is establishing this year two stations on Devon Island, N.W.T., for glaciological, marine biological and meteorological studies. Opportunities exist at stations on the Ellesmere Island Ice Shelf and Ice Island T-3 for work in glaciology, sea ice, oceanography, and marine biology. The Institute maintains one small glacier station and is associated with another on the northern slope of Alaska's Brooks Range. These are only a few of the northern research facilities active in 1960 .

I am further pleased to announce the Arctic Institute will entertain proposals for support of field research in Antarctica. Applications must be submitted a full year in advance of an Antarctic field season.

Further information about the programme and application forms are available on request from the Arctic Institute of North America, 3485 University Street, Montreal 2, P.Q. or 1530 P Street, N.W., Washington 5, D.C. Applications for 1960 grants should be initiated before November 1, 1960. The Institute will be most grateful to you for presenting this information to your readers. [Although it is too late for applications for grants to be made in respect of 1960, this letter is published to draw attention to the system.]

ROBERT W. MASON

ARCTIC INSTITUTE OF NORTH AMERICA, PROJECT CO-ORDINATOR

3485 UNIVERSITY STREET,

MONTREAL

2 EAST 63RD STREET,

NEW YORK

15 August 1960 